
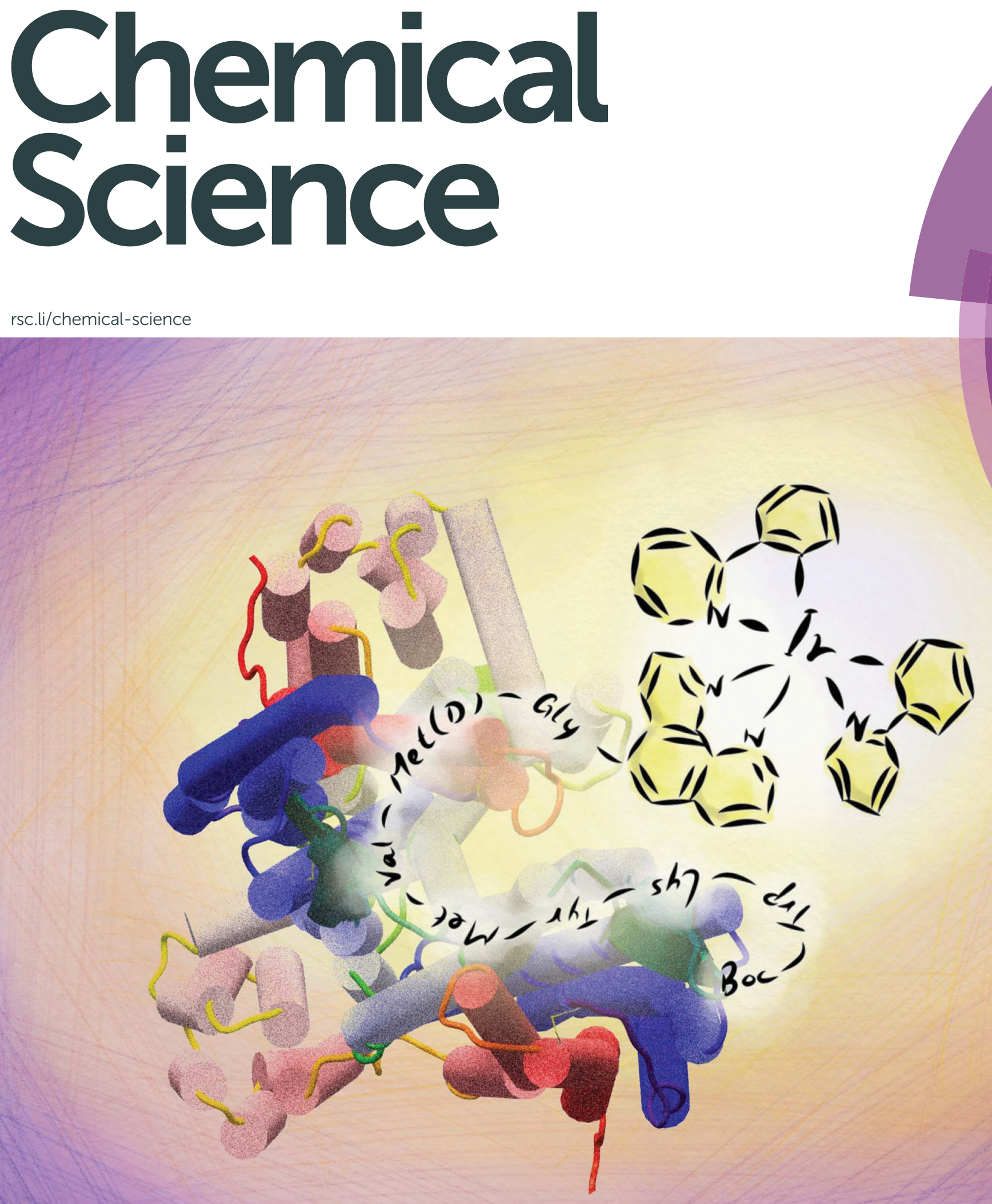

ISSN 2041-6539 
Check for updates

Cite this: Chem. Sci., 2018, 9, 8171

๑ All publication charges for this article have been paid for by the Royal Society of Chemistry

\section{A long-lived peptide-conjugated iridium(III) complex as a luminescent probe and inhibitor of the cell migration mediator, formyl peptide receptor $2 \dagger$}

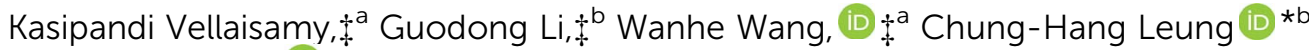 \\ and Dik-Lung Ma (D) *a
}

Formyl peptide receptors play important biological and therapeutic roles in wound repair and inflammatory diseases. In this work, we present a luminescent iridium(III) complex (6) conjugated with the peptide agonist WKYMVm as a luminescent formyl peptide receptor 2 (FPR2) imaging probe in living cells. Complex 6 displayed ideal cell imaging characteristics, high photostability and low cytotoxicity. Competition assays with a known FPR2 antagonist, WRW4, and siRNA knockdown experiments both revealed that complex 6 selectively targeted FPR2 in living HUVEC cells. Moreover, complex 6 regulated FPR2 signalling in HUVEC cells as shown using a mechanical scratch assay. Finally, complex 6 reduced epithelial cell migration capacity and inhibited lipoxin A4 (LXA4)-triggered cell migration in HUVEC cells, demonstrating the ability of this complex to inhibit FPR2 in living cells. To our knowledge, this is the first long-lived probe for imaging FPR2 in living cells.
Received 21st June 2018

Accepted 29th September 2018

DOI: $10.1039 / \mathrm{c} 8 \mathrm{sc} 02733 a$

rsc.li/chemical-science neurodegenerative diseases. ${ }^{7}$ Therefore, the development of highly sensitive and selective probes for FPRs is required for further elucidating the biological and therapeutic roles of FPRs in wound repair and disease.

Noninvasive molecular-imaging techniques are powerful tools for studying biological processes in living systems., ${ }^{\mathbf{8 9}}$ Peptide-based imaging probes have been increasingly studied due to their compatibility with living systems, high binding affinity, and adequate permeability. ${ }^{10,11}$ For FPRs, an FPR1 targetable cFLFLF peptide complexed with various radioactive metals (e.g. $\mathrm{Ga}(\mathrm{III}), \mathrm{In}(\mathrm{III}), \mathrm{Gd}(\mathrm{III}),{ }^{99} \mathrm{Tc}$ and ${ }^{64} \mathrm{Cu}$ ) has been widely employed for imaging of inflammation in various animal models. ${ }^{12-16}$ Peptide-based fluorescent probes have received considerable recent attention due to their high sensitivity, selectivity, and safe imaging performance. ${ }^{\mathbf{1 7}}$ For example, peptide-based fluorescent probes have been reported for imaging matrix metalloproteinase (MMP) $)^{\mathbf{1 8 , 1 9}}$ and cysteine protease. ${ }^{20-22}$ However, only a few peptide-based fluorescent probes have been reported for FPR1 ${ }^{16,23}$ and FPR2. ${ }^{24}$

Transition metal complexes are emerging as a promising class of luminophores for studying biological processes in living cells, ${ }^{25-28}$ due to their long emission lifetime, large Stokes shift, and high photostability. However, the poor cell permeability of transition metal complex-based probes still remains a challenge for their further bioimaging application. One effective strategy to overcome this bottleneck is the conjugation of a transition metal complex with a specifically targetable peptide. ${ }^{\mathbf{2 9 0}}$ In recent years, considerable effort has been made to develop

\footnotetext{
a Department of Chemistry, Hong Kong Baptist University, Kowloon Tong, Hong Kong, China.E-mail: edmondma@hkbu.edu.hk

${ }^{b}$ State Key Laboratory of Quality Research in Chinese Medicine, Institute of Chinese Medical Sciences, University of Macau, Macao, China.E-mail: duncanleung@umac.mo $\dagger$ Electronic supplementary information (ESI) available. See DOI: 10.1039/c8sc02733a

\$ These authors contributed equally to this work.
} 
transition metal complex-peptide conjugates as imaging probes, ${ }^{29,31}$ such as cobaltocenium-peptide conjugates for studying cellular uptake, ${ }^{32}$ ruthenium-short peptide conjugates for nuclear staining, ${ }^{33}$ and ruthenium-cyclic RGD peptide conjugates for targeting integrin receptors. ${ }^{34}$ Considering the additional favorable characteristics possessed by iridium(III) complexes including high quantum yields and tunable luminescence, ${ }^{35,36}$ the combination of an iridium(III) complex and a peptide may provide additional synergism for bioimaging applications. However, peptide-functionalized iridium(III) complexes as bioimaging probes have not been widely explored..$^{37-42}$

The hexapeptide WKYMVm is a selective FPR2 agonist with high affinity, which was identified through screening of a synthetic peptide library. ${ }^{\mathbf{4 3 , 4 4}}$ WKYMVm promoted recovery from tissue damage via an FPR2-dependent pathway in various disease models, ${ }^{44}$ such as cutaneous wound healing of diabetic mice, ${ }^{45}$ and a hindlimb ischemia model. ${ }^{46}$ In this study, we conjugated WKYMVm to a cyclometalated iridium(III) complex to develop a new luminescent probe for FPR2 (Fig. 1). This peptide-conjugated cyclometalated iridium(III) complex 6 visualized FPR2 in living cells. As complex 6 bears the peptide ligand (WKYMVm) agonist, we believe that the peptideconjugated complex would not only be able to effectively recognize FPRs, but also regulate FPR2-mediated functions (Scheme 1). ${ }^{47}$ To our knowledge, this is the first report of an iridium(III) complex for visualizing FPR2 in living cells.

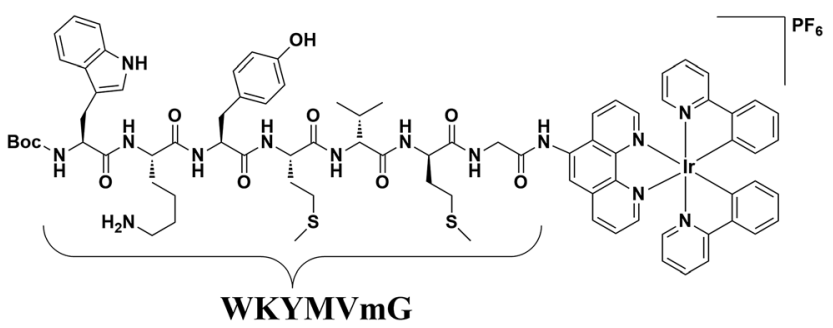

Fig. 1 Chemical structure of the peptide iridium(III) complex as an FPR2 probe.

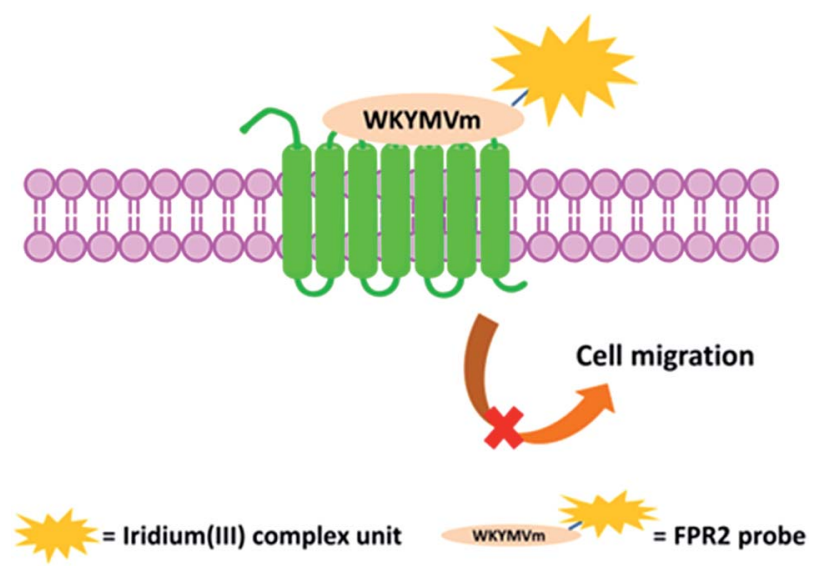

Scheme 1 Schematic diagram of the peptide iridium(III) complex as a luminescent probe and inhibitor of FPR2 in living cells.

\section{Results and discussion}

\section{Synthesis of peptide-conjugated iridium(III) complex 6}

The peptide-conjugated iridium(III) complex 6 has the general structure of $\left[\operatorname{Ir}\left(\mathrm{C}^{\wedge} \mathrm{N}\right)_{2}\left(\mathrm{~N}^{\wedge} \mathrm{N}\right)\right]\left(\mathrm{PF}_{6}\right)$ (where $\mathrm{C}^{\wedge} \mathrm{N}=$ 2-phenylpyridine (ppy), and $\mathrm{N}^{\wedge} \mathrm{N}=1,10$-phenanthrolin-5-amineWKYMVmG). We envisaged that conjugating the WKYMVm agonist to an iridium(III) scaffold could afford useful probes for FPR2. To synthesize the iridium(III) complex $\mathbf{6}$, the doubly allylprotected tripeptide (Boc-Trp(Alloc)-Lys(Alloc)-Tyr-OMe) 1 was first synthesized using a standard solution phase peptide protection and deprotection strategy. Peptide 1 was hydrolyzed under basic conditions using lithium hydroxide (LiOH) in THF/ water $(1: 1)$ to furnish the corresponding Boc-protected acid (Boc-Trp(Alloc)-Lys(Alloc)-Tyr-COOH) 3 (Scheme 2). Meanwhile, 2-amino- $N$-(1,10-phenanthrolin-5-yl)acetamide is coupled with the tripeptide Boc-Met-Val-D-Met-COOH. The resulting $\mathrm{N}^{\wedge} \mathrm{N}$ ligand Boc-Met-Val-Met-Gly-1,10-phenanthroline was isolated in good yield (90\%), and was complexed by reacting with a dimeric iridium precursor bearing 2-phenylpyridine (ppy) $\left(\mathrm{C}^{\wedge} \mathrm{N}\right)$ ligands in dichloromethane $(\mathrm{DCM}) / \mathrm{MeOH}(1: 1)$ to generate the tetrapeptide-conjugated iridium(III) complex 2 . Meanwhile, the tetrapeptide-conjugated iridium(III) complex 2 was de-protected using trifluoroacetic acid (TFA) in dry DCM to generate the corresponding amine salt 4. Subsequently, the Boc-protected acid 3 was coupled with amine 4 employing standard 1-ethyl-3-(3-dimethylaminopropyl)carbodiimide (EDCI) coupling conditions to yield the conjugated complex 5. Finally, allyl carbomate deprotection of compound $\mathbf{5}$ with a catalytic amount of $\mathrm{Pd} / \mathrm{C} / \mathrm{TES}$ in methanol $(\mathrm{MeOH})$ yielded complex 6 in good yield after silica gel column chromatography purification. The new complex 6 was fully characterized by ${ }^{1} \mathrm{H}$ NMR spectroscopy and high-resolution mass spectrometry (HRMS) (Fig. S5-S7†).

\section{Luminescence profile of complex 6}

The photophysical properties of complex 6 were determined in acetonitrile (ACN) and are described in Table S1.† Notably,

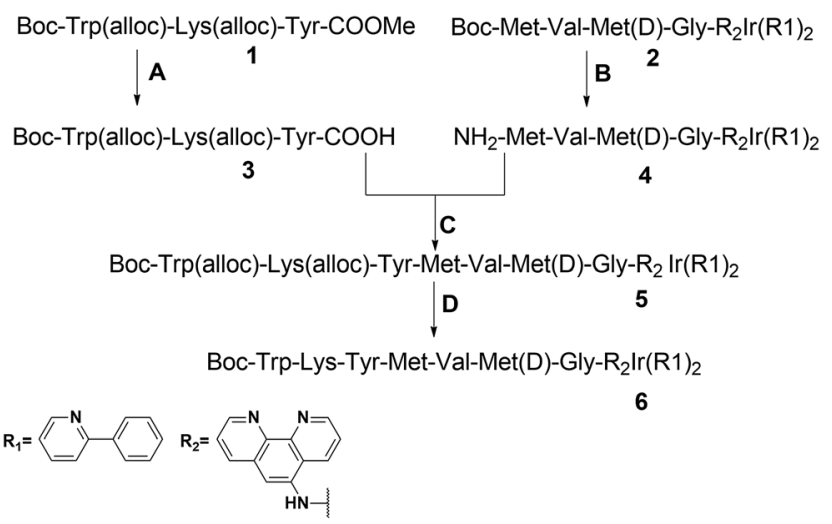

Scheme 2 Synthetic route to the peptide iridium(III) complex. Conditions: (A) $\mathrm{LiOH}, \mathrm{THF} / \mathrm{H}_{2} \mathrm{O}(1: 1), 0$ to r.t., yield $=95 \%$; (B) TFA/ $\mathrm{DCM}$, quantitatively; (C) $\mathrm{Et}_{3} \mathrm{~N}, \mathrm{EDCl}, \mathrm{DCM}$, yield $=63 \%$; (D) $\mathrm{Pd} / \mathrm{C}$, $\mathrm{PhSiH}_{3}, \mathrm{MeOH}$, r.t., yield $=73 \%$ (alloc $=$ allyloxycarbonyl). 
complex 6 showed a good quantum yield (0.245) and a long luminescence lifetime $(4.62 \mu \mathrm{s})$. The UV-Vis absorption spectrum of complex 6 is presented in Fig. S8. $\dagger$ Complex 6 showed maximum excitation at $291 \mathrm{~nm}$ and maximum emission at $576 \mathrm{~nm}$ (Fig. S9†). The luminescence intensity of complex 6 was unchanged by the addition of $0.3 \mu \mathrm{g} \mathrm{mL}{ }^{-1}$ FPR2 in PBS (pH 7.4) buffer (Fig. S10†). Moreover, complex 6 showed no response to common biological interferents in living cells, including amino acids, common metal ions $\left(\mathrm{Zn}^{2+}, \mathrm{Mg}^{2+}, \mathrm{Ca}^{2+}, \mathrm{Fe}^{3+}\right.$ and $\left.\mathrm{Cu}^{2+}\right)$, and other small molecules or proteins (ATP, NADH and BSA) (Fig. S11†). Importantly, complex 6 showed excellent photostability, as luminescence intensity was not impaired even after $1800 \mathrm{~s}$ of continuous irradiation at $365 \mathrm{~nm}$ (Fig. S12 $\dagger$ ). Taken together, these results demonstrate the utility of complex 6 as a long-lived and permanent probe.

\section{Cytotoxicity and cell imaging of living cells}

Considering the promising luminescence profile of the peptideconjugated iridium(III) complex 6, its cytotoxicity was assessed in HUVEC cells using the 3-(4,5-dimethylthiazol-2-yl)-2,5diphenyltetrazolium bromide (MTT) assay. Encouragingly, complex 6 showed an $\mathrm{IC}_{50}$ value of $63.09 \mu \mathrm{M}$ even after 48 hours treatment (Fig. $\mathrm{S} 13 \dagger$ ), indicating that this complex is relatively nontoxic to HUVEC cells under the experimental conditions and rendering it suitable for cell imaging experiments. The cytotoxicity of compound 6 was further evaluated in three other cell lines, including a human hepatic cell line (LO2), a cervical cancer cell line (HeLa), and a breast cancer cell line (MDA-MB231) using the MTT assay. Complex 6 showed low cytotoxicity to LO2, HeLa, and MDA-MB-231 cell lines with $\mathrm{IC}_{50}$ values of $>100$, $>100$, and $52.48 \mu \mathrm{M}$ (Fig. S14 $\dagger$ ), respectively. Furthermore, to determine whether the conjugation of WKYMVm affects the toxicity of the iridium moiety, the cytotoxicity of the parent iridium(III) scaffold S1 (Fig. S15†) was examined. As shown in Fig. S16, $\dagger$ complex S1 showed an $\mathrm{IC}_{50}$ value of $14.13 \mu \mathrm{M}$ after $48 \mathrm{~h}$ treatment in HUVEC cells ( $c f .63 .09 \mu \mathrm{M}$ for complex 6). This result suggests that the incorporation of the peptide WKYMVm into an iridium(III) scaffold can reduce the cytotoxicity of the metal moiety. Taken together, these results indicate that complex 6 is non-toxic enough to use for cell imaging experiments.

We next studied the application of complex 6 for cell imaging. HUVEC cells, known to express FPR2, ${ }^{48}$ were incubated with complex $6(0,3,10,30$ and $60 \mu \mathrm{M})$ for $1 \mathrm{~h}$ and then washed with phosphate buffer (PBS). Luminescence imaging was performed using confocal laser scanning microscopy with excitation at $488 \mathrm{~nm}$. Encouragingly, the luminescence intensity of treated HUVEC cells increased with the dosage of complex 6 (Fig. 2).

We presume that complex 6 could interact with FPR2 via its conjugated peptide agonist moiety, thereby resulting in an enhanced luminescence of the cells. A subsequent time-course experiment was performed to evaluate the kinetics of the luminescence response of complex 6 in living cells. The result showed that the yellow luminescence of complex $6(30 \mu \mathrm{M})$ increased and reached a plateau within $1 \mathrm{~h}$ incubation in

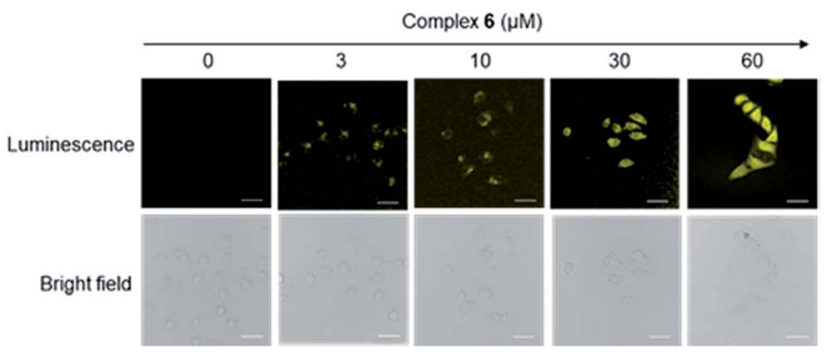

Fig. 2 Luminescence and bright-field images of HUVEC cells incubated with 0 to $60 \mu \mathrm{M}$ of complex 6 for $1 \mathrm{~h}$. Scale bar $=50 \mu \mathrm{m}$.

HUVEC cells. Thus, a reaction time of $1 \mathrm{~h}$ was chosen for subsequent experiments (Fig. 3).

\section{Validation of FPR2 binding in HUVEC cells}

To provide further evidence that complex 6 interacted with FPR2 in living cells, we preincubated HUVEC cells with various concentrations of the FPR2-selective antagonist WRW4 (1, 3, 10 and $30 \mu \mathrm{M})$ for $1 \mathrm{~h}$, before staining with complex $6(30 \mu \mathrm{M})$ for $1 \mathrm{~h}$. Notably, the luminescence intensity of complex 6 decreased in the presence of WRW4 (Fig. 4), which is presumably due to competitive binding to FPR2, thereby blocking the interaction between complex 6 and the receptor. To verify the role of the WKYMVm peptide in probe $\mathbf{6}$, luminescence imaging experiments were also performed with the parent iridium(III) scaffold $\mathbf{S 1}$ and the tetrapeptide-conjugated complex $\mathbf{2}$ under the same conditions. The results showed that there was no significant

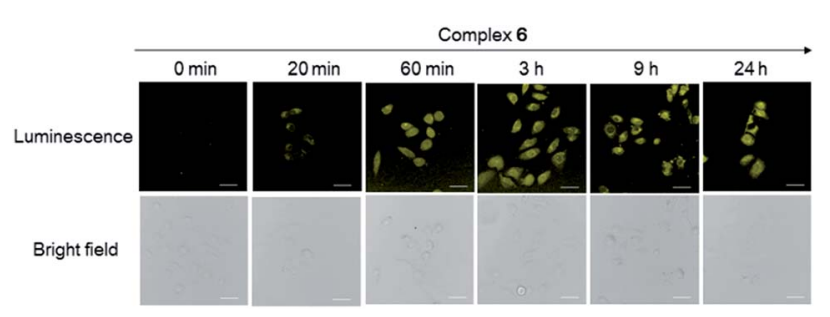

Fig. 3 Luminescence and bright-field images of HUVEC cells incubated with $30 \mu \mathrm{M}$ of complex 6 at different time intervals. Scale bar $=$ $15 \mu \mathrm{m}$. HUVEC cell line stained by complex 6 at different incubation times (0 min, $20 \mathrm{~min}, 60 \mathrm{~min}, 3 \mathrm{~h}, 9 \mathrm{~h}$ and 24 h). Scale bar $=100 \mu \mathrm{m}$.

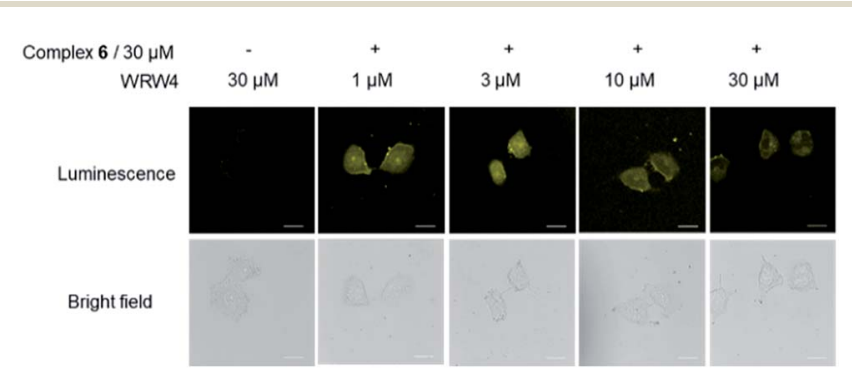

Fig. 4 Luminescence and bright-field images of HUVEC cells. HUVEC cells were pretreated with or without WRW4 at various concentrations (1-30 $\mu \mathrm{M})$ for $1 \mathrm{~h}$, followed by staining with complex $6(30 \mu \mathrm{M})$ for $1 \mathrm{~h}$. Scale bar $=50 \mu \mathrm{m}$. 
change in the luminescence intensity of $\mathbf{S 1}$ or $\mathbf{2}$ after pretreatment with WRW4 in HUVEC cells (Fig. S17†), suggesting that the WKYMVm peptide motif in complex 6 plays a key role in targeting FPR2 protein.

To further verify the targeting of FPR2 by complex 6 in living HUVEC cells, siRNA knockdown experiments were employed. The levels of FPR2 reduced significantly after treatment of HUVEC cells with FPR2 siRNA (Fig. 5a). Next, complex 6 was introduced into FPR2 knockdown HUVEC cells. As shown in Fig. 5b, the luminescence of complex 6 reduced significantly, indicating that the emission intensity of the complex was correlated with the level of FPR2 in living cells. Taken together, these results suggest that complex 6 may act as an FPR2 imaging probe in living cells, allowing the visualization of FPR2 in a non-invasive manner and potentially enabling the visual study of its biological dynamics. ${ }^{49-51}$

\section{Complex 6 could inhibit the lipoxin A4 (LXA4)-triggered cell migration in HUVEC cells}

Previous reports have shown that FPR2 activation could stimulate the invasion and migration of epithelial cells. ${ }^{\mathbf{4 4 5 2}}$ Therefore, we employed the scratch assay to study FPR2's role in cell migration. The scratch assay was first performed in FPR2silenced HUVEC cells to verify the role of FPR2 in cell migration (Fig. S18A $\dagger$ ). Cell migration capacity was evaluated by quantifying the total distance that the HUVEC cells moved from the edge of the scratch (marked by imaginary horizontal lines) toward the center of the scratch. ${ }^{53}$ After treatment with negative control (NC) siRNA or FPR2 siRNA, the monolayers of HUVECs were scratched linearly with a $200 \mu \mathrm{L}$ pipette tip, and images of wounded monolayer were taken at $12 \mathrm{~h}$. The results showed that FPR2 silencing decreased the migration of HUVEC cells compared to cells treated with NC siRNA. This indicates that FPR2 is correlated with the cell migration capacity of HUVECs, which is consistent with previous reports. ${ }^{54,55}$

To further evaluate the role of complex 6 as a regulator of FPR2 signaling in HUVEC cells, the scratch assay was repeated in the presence of complex 6 . As depicted in Fig. S18B, $\dagger$ complex 6 reduced the migration of HUVEC cells in a dose-dependent manner at 12 and $24 \mathrm{~h}$, indicating that complex 6 may be a metal-based inhibitor of FPR2 in HUVEC cells. LXA4 is a bioactive eicosanoid with FPR2 agonist activity, triggering

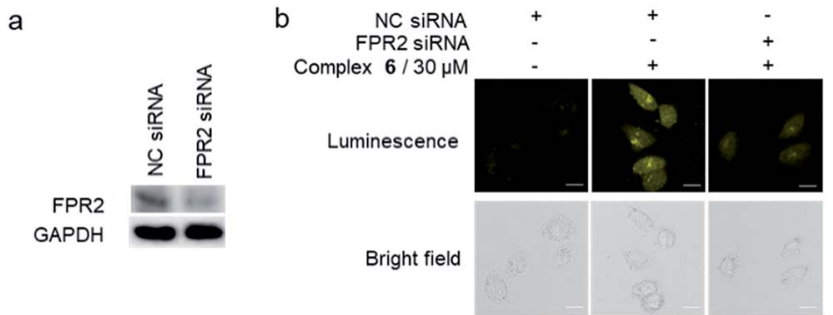

Fig. 5 (a) FPR2 is down-regulated after FPR2 siRNA pretreatment. GAPDH was used as a loading control. (b) Normal HUVEC cells and FPR2 knockdown HUVEC cells were stained with or without complex 6 $(30 \mu \mathrm{M})$ for $1 \mathrm{~h}$. Scale bar $=50 \mu \mathrm{m}$. epithelial cell migration. ${ }^{6,47}$ The migration capacity of HUVEC cells treated with $1 \mathrm{nM}$ of LXA4 was significantly enhanced compared to vehicle-induced HUVEC cells (Fig. 6). However, the LXA4-stimulated migration of HUVEC cells was significantly decreased in the presence of complex $6(30 \mu \mathrm{M})$ after $12 \mathrm{~h}$ and $24 \mathrm{~h}$. This result demonstrates that complex 6 is a potential regulator of FPR2-mediated functions in living HUVEC cells.

\section{Experimental}

\section{Synthesis of compound 3}

Compound 1 was synthesised using standard solution phase peptide synthesis and it was characterised by NMR and HRMS. Compound 1: ${ }^{1} \mathrm{H}$ NMR (400 MHz, $\mathrm{CDCl}_{3}$ ) $\delta 8.15(\mathrm{~s}, 1 \mathrm{H}), 7.58(\mathrm{~d}$, $J=7.7 \mathrm{~Hz}, 1 \mathrm{H}), 7.48$ (s, 1H), $7.32(\mathrm{dd}, J=16.5,8.9 \mathrm{~Hz}, 2 \mathrm{H}), 7.23$ $(\mathrm{d}, J=7.3 \mathrm{~Hz}, 1 \mathrm{H}), 6.95(\mathrm{~d}, J=8.3 \mathrm{~Hz}, 2 \mathrm{H}), 6.76(\mathrm{~d}, J=8.0 \mathrm{~Hz}$, 2H), $6.46(\mathrm{~s}, 1 \mathrm{H}), 6.03(\mathrm{~m}, 1 \mathrm{H}), 5.89(\mathrm{~d}, J=5.8 \mathrm{~Hz}, 1 \mathrm{H}), 5.59$ $(\mathrm{s}, 1 \mathrm{H}), 5.46(\mathrm{t}, J=3.9 \mathrm{~Hz}, 1 \mathrm{H}), 5.43(\mathrm{~d}, J=1.2 \mathrm{~Hz}, 1 \mathrm{H}), 5.36(\mathrm{~s}$, $1 \mathrm{H}), 5.33(\mathrm{~d}, J=0.9 \mathrm{~Hz}, 1 \mathrm{H}), 5.29(\mathrm{~d}, J=17.4 \mathrm{~Hz}, 1 \mathrm{H}), 3.70(\mathrm{~d}, J=$ $10.2 \mathrm{~Hz}, 3 \mathrm{H}), 1.52$ (s, 2H), $1.42(\mathrm{~s}, 2 \mathrm{H}), 1.39$ (s, 9H), 1.24 (d, $J=$ $6.8 \mathrm{~Hz}, 3 \mathrm{H}) .{ }^{13} \mathrm{C} \mathrm{NMR}\left(101 \mathrm{MHz}, \mathrm{CDCl}_{3}\right) \delta 172.19,171.74,171.54$, 156.00, 155.79, 155.58, 132.49, 131.38, 130.33, 127.04, 124.97, $123.78,123.10,119.59,119.18,118.11,116.70,115.69,115.29$, $80.52,77.37,77.25,77.05,76.73,67.71,66.02,65.90,54.74$, 53.18, 52.52, 38.97, 36.80, 31.84, 28.30, 22.05, 15.31, 1.06 . HRMS: calcd. for $\mathrm{C}_{39} \mathrm{H}_{49} \mathrm{~N}_{5} \mathrm{O}_{11}[\mathrm{M}+\mathrm{Na}]^{+}: 800.3477$ found: 800.3446. Hydrolysis of the C-terminal methyl ester of compound 1 hydrolysed using LiOH in tetrahydrofuran (THF)/ $\mathrm{H}_{2} \mathrm{O}(1: 1)$ at 0 to r.t. gave the corresponding acid 3 in good yield (95\%).

\section{Synthesis of compound 4}

The compound 2 peptide precursor was obtained using standard peptide coupling and the peptide precursor Boc-Met-Val-Met(D)$\mathrm{COOH}$ was coupled with 2-amino- $N$-(1,10-phenanthrolin-5-yl) acetamide to give the corresponding peptide-conjugated

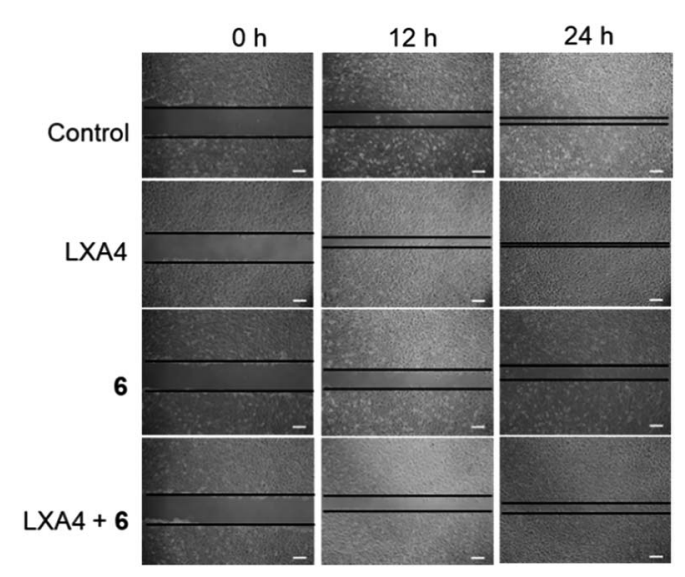

Fig. 6 Complex 6 could inhibit the LXA4-triggered cell migration in HUVEC cells. Cell migration of epithelial cells grown as monolayers on plastics for 12 and $24 \mathrm{~h}$ after treatment with either ethanol control, LXA4 (1 nM), complex 6, or complex 6 in the presence of LXA4. The horizontal lines indicate the wound edge. Scar bar $=200 \mu \mathrm{m}$. 
ligand. The peptide attached ligand is reacted with the iridium2-phenylpyridine dimer in MeOH/DCM (1:1) to get the corresponding peptide iridium(III) complex 2. Compound 2: ${ }^{1} \mathrm{H}$ NMR (400 MHz, DMSO) $\delta 10.45$ (s, 1H), 8.97 (d, $J=8.8 \mathrm{~Hz}, 1 \mathrm{H}), 8.86$ (d, $J=8.3 \mathrm{~Hz}, 1 \mathrm{H}), 8.60$ (m, 1H), 8.24 (dd, $J=13.1,6.6 \mathrm{~Hz}, 3 \mathrm{H}), 8.08$ $(\mathrm{m}, 2 \mathrm{H}), 7.97(\mathrm{~m}, 3 \mathrm{H}), 7.87(\mathrm{dd}, J=11.0,7.3 \mathrm{~Hz}, 2 \mathrm{H}), 7.73(\mathrm{~s}, 1 \mathrm{H})$, $7.45(\mathrm{~d}, J=5.6 \mathrm{~Hz}, 2 \mathrm{H}), 7.05(\mathrm{t}, J=7.0 \mathrm{~Hz}, 3 \mathrm{H}), 6.95$ (ddd, $J=$ 12.0, 11.6, $6.0 \mathrm{~Hz}, 4 \mathrm{H}), 6.26(\mathrm{t}, J=7.6 \mathrm{~Hz}, 2 \mathrm{H}), 4.41(\mathrm{~s}, 1 \mathrm{H}), 4.15$ $(\mathrm{dd}, J=21.5,6.8 \mathrm{~Hz}, 3 \mathrm{H}), 4.04(\mathrm{~s}, 2 \mathrm{H}), 2.41(\mathrm{~s}, 3 \mathrm{H}), 1.99(\mathrm{~m}, 6 \mathrm{H})$, 1.93 (s, 1H), $1.90(\mathrm{~s}, 1 \mathrm{H}), 1.33(\mathrm{~m}, 9 \mathrm{H}), 0.81$ (s, 7H). ${ }^{13} \mathrm{C}$ NMR (101 MHz, DMSO) $\delta 171.94,171.72,171.54,170.99,169.15,166.83$, 155.39, 150.74, 150.03, 149.68, 149.08, 146.54, 144.03, 143.97, $138.70,138.28,134.49,133.67,131.24,131.19,130.73,130.22$, $127.25,127.08,126.52,125.06,123.89,122.39$, 119.97, 78.25, $57.95,57.56,57.35,57.22,53.82,53.57,53.39,52.91,51.95,51.91$, 51.70, 42.92, 31.75, 31.61, 30.62, 29.69, 29.52, 28.12, 19.11, 17.75, 14.61, 14.56, 14.49. HRMS: calcd. for $\mathrm{C}_{43} \mathrm{H}_{29} \mathrm{~F}_{10} \mathrm{IrN}_{5} \mathrm{O}_{3} \mathrm{P}[\mathrm{M}-$ $\left.\mathrm{PF}_{6}\right]^{+}: 1214.5031$ found: 1214.5373 . Then, Boc-Met-Val-Met-Gly$\operatorname{Ir}(\mathrm{R} 1)_{2}$ is converted into compound 4 ( $\mathrm{NH}_{2}$-Met-Val-Met-Gly$\left.\operatorname{Ir}(\mathrm{R} 1)_{2}\right)$ using TFA in DCM in quantitative yield.

\section{Synthesis of compounds 5 and 6}

To a stirred solution of Boc-Trp(alloc)-Lys(alloc)-Tyr-COOH (250 mg, $0.32 \mathrm{mmol}$ ) and $\mathrm{NH}_{2}$-Met-Val-Met-Gly-Ir(R1) 2 (445 mg, $0.353 \mathrm{mmol}$ ) in $20 \mathrm{~mL}$ of dry DCM were added triethylamine $\left(\mathrm{Et}_{3} \mathrm{~N}\right)(93 \mu \mathrm{L}, 0.64 \mathrm{mmol})$ and then EDCI (122 mg, $\left.0.64 \mathrm{mmol}\right)$. The reaction mixture was stirred overnight, and the reaction was followed by thin layer chromatography (TLC) (DCM/MeOH, 95/ $5)$. The reaction was stopped and washed with $\mathrm{H}_{2} \mathrm{O}(50 \mathrm{~mL})$, $5 \%$ hydrochloric acid $(\mathrm{HCl})(50 \mathrm{~mL})$, and saturated sodium bicarbonate $\left(\mathrm{NaHCO}_{3}\right)(50 \mathrm{~mL})$. After drying over sodium sulphate $\left(\mathrm{Na}_{2} \mathrm{SO}_{4}\right)$, the solvent was evaporated in vacuo to give a yellow solid which was purified using column chromatography to give $0.41 \mathrm{~g}$ of the pure Boc-Trp(alloc)-Lys(alloc)-Tyr-Met-ValMet-Gly-Ir(R1) 2 (5) as yellow crystals in good yield (63\%).

To a stirred suspension of Boc-Trp(alloc)-Lys(alloc)-Tyr-MetVal-Met-Gly-Ir(R1) 2 (5) (30 mg, $0.014 \mathrm{mmol}$ ) and 10\% Pd/C (10 mg) in $5 \mathrm{~mL}$ of $\mathrm{MeOH}$ was added triethylsilane $(0.1 \mathrm{~mL}, 0.14 \mathrm{mmol})$ drop-wise under argon. After completion of reaction (TLC), the mixture was filtered through celite, and the filtrate was concentrated under vacuum. The crude product was purified by short silica gel column chromatography, eluting with $10 \% \mathrm{MeOH}-\mathrm{DCM}$, to give $20 \mathrm{mg}$ of 6 as light-yellow solid with a yield of $73 \%$, and an overall yield of $43 \%$. Iridium(III) complex 6: ${ }^{1} \mathrm{H}$ NMR $(400 \mathrm{MHz}$, DMSO) $\delta 10.85(\mathrm{~s}, 1 \mathrm{H}), 9.79(\mathrm{~d}, J=5.7 \mathrm{~Hz}, 1 \mathrm{H}), 9.51(\mathrm{~d}, J=6.0 \mathrm{~Hz}$, $1 \mathrm{H}), 8.26(\mathrm{~d}, J=7.5 \mathrm{~Hz}, 1 \mathrm{H}), 8.17(\mathrm{~d}, J=8.2 \mathrm{~Hz}, 1 \mathrm{H}), 8.08(\mathrm{~m}, 1 \mathrm{H})$, $8.01(\mathrm{~d}, J=7.6 \mathrm{~Hz}, 1 \mathrm{H}), 7.98(\mathrm{~s}, 1 \mathrm{H}), 7.95(\mathrm{~s}, 1 \mathrm{H}), 7.87(\mathrm{~s}, 2 \mathrm{H}), 7.78$ $(\mathrm{d}, J=8.2 \mathrm{~Hz}, 1 \mathrm{H}), 7.72(\mathrm{~d}, J=7.9 \mathrm{~Hz}, 1 \mathrm{H}), 7.57(\mathrm{~d}, J=7.0 \mathrm{~Hz}, 2 \mathrm{H})$, $7.44(\mathrm{~m}, 1 \mathrm{H}), 7.30(\mathrm{~s}, 1 \mathrm{H}), 7.21(\mathrm{~s}, 2 \mathrm{H}), 7.09(\mathrm{~s}, 1 \mathrm{H}), 7.02(\mathrm{~s}, 2 \mathrm{H})$, $6.95(\mathrm{~s}, 2 \mathrm{H}), 6.88(\mathrm{~m}, 1 \mathrm{H}), 6.82(\mathrm{~m}, 1 \mathrm{H}), 6.75(\mathrm{~m}, 1 \mathrm{H}), 6.68(\mathrm{~m}, 1 \mathrm{H})$, $6.23(\mathrm{~d}, J=7.1 \mathrm{~Hz}, 1 \mathrm{H}), 5.98(\mathrm{dd}, J=17.2,10.0 \mathrm{~Hz}, 1 \mathrm{H}), 5.84(\mathrm{~d}, J=$ $17.1 \mathrm{~Hz}, 1 \mathrm{H}), 5.64$ (d, J= 7.4 Hz, 1H), 5.36 (s, 1H), 4.47 (s, 1H), 4.42 $(\mathrm{s}, 1 \mathrm{H}), 4.20(\mathrm{~s}, 1 \mathrm{H}), 4.12(\mathrm{~s}, 2 \mathrm{H}), 3.57$ (d, J=6.3 Hz, 2H), 2.98 (s, $3 \mathrm{H}), 2.87(\mathrm{~s}, 2 \mathrm{H}), 2.41(\mathrm{~d}, J=7.2 \mathrm{~Hz}, 2 \mathrm{H}), 2.00(\mathrm{~s}, 5 \mathrm{H}), 1.82(\mathrm{~s}, 2 \mathrm{H})$, $1.28(\mathrm{~s}, 7 \mathrm{H}), 1.21(\mathrm{~s}, 3 \mathrm{H}), 1.12(\mathrm{~s}, 2 \mathrm{H}), 0.83(\mathrm{~s}, 5 \mathrm{H})$. HRMS: calcd. for $\mathrm{C}_{82} \mathrm{H}_{94} \mathrm{~F}_{6} \mathrm{IrN}_{14} \mathrm{O}_{10} \mathrm{~S}_{2} \mathrm{P}\left[\mathrm{M}-\mathrm{PF}_{6}\right]^{+}: 1691.634757$ found: 1692.1516.

\section{Materials and cell lines}

All chemicals were purchased from Sigma-Aldrich and were used as received. Lipofectamine ${ }^{\mathrm{TM}} 3000$ reagent was purchased from Invitrogen (Carlsbad, CA, USA). Fetal bovine serum (FBS) and Dulbecco's Modified Eagle's Medium (DMEM) were purchased from Gibco BRL (Gaithersburg, MD, USA).

\section{Cytotoxicity assay}

HUVEC cells were seeded in 96-well plates at a density of 5000 cells per well. After $12 \mathrm{~h}$ incubation, the cells were incubated with complex 6 at the indicated concentrations for $48 \mathrm{~h}$. After incubation, $10 \mu \mathrm{L}$ of $5 \mathrm{mg} \mathrm{mL}^{-1}$ MTT reagent was added to each well for $4 \mathrm{~h}$. $100 \mu \mathrm{L}$ of DMSO was then added to each well, and the intensity of absorbance was determined using a SpectraMax M5 microplate reader at a wavelength of $570 \mathrm{~nm}$.

\section{Cell imaging}

HUVEC cells were seeded into a glass-bottomed dish $(35 \mathrm{~mm}$ dish with $20 \mathrm{~mm}$ wells) and incubated for $24 \mathrm{~h}$. Complex 6 was added to cells for indicated time periods or concentrations, followed by washing with phosphate-buffered saline (PBS) three times. The luminescence imaging of complex 6 in cells was carried out using a Leica TCS SP8 confocal laser scanning microscope system. The excitation wavelength was $488 \mathrm{~nm}$.

\section{FPR2 knockdown assay}

HUVEC cells were seeded in 6-well plates at about $80 \%$ confluence in DMEM for $12 \mathrm{~h}$. Lipofectamine ${ }^{\mathrm{TM}} 3000$ reagent and siRNA were gently mixed in FBS-free DMEM medium. After 15 min incubation at room temperature, $500 \mu \mathrm{L}$ of siRNA-lipid complex was directly added to cells in $1.5 \mathrm{~mL}$ DMEM culture medium. Then, HUVEC cells were incubated at $37^{\circ} \mathrm{C}$ in ${\mathrm{a} \mathrm{CO}_{2}}$ incubator for $48 \mathrm{~h}$ before use.

\section{Immunoblotting}

HUVEC cells were washed twice with pre-chilled PBS after knockdown treatment, and harvested in lysis buffer. The protein concentration was determined by using the BCA assay. Total proteins were separated by SDS-polyacrylamide gel electrophoresis and then transferred onto polyvinylidene difluoride membranes (Millipore). After incubation with blocking buffer for $1 \mathrm{~h}$ at r.t., the membranes were incubated with primary antibodies at $4{ }^{\circ} \mathrm{C}$ overnight and secondary antibodies for $1 \mathrm{~h}$ incubation at room temperature. The protein bands were then stained with ECL Western Blotting Detection Reagent (GE Healthcare) and visualized using the ChemiDocTM MP Imaging System.

\section{In vitro wound migration assay}

HUVEC cells were seeded in 6-well plates at about 90\% confluence in DMEM overnight. The cells were scratched along the diameter of the well. The monolayers of HUVECs were scratch wounded with a $200 \mu \mathrm{L}$ pipette tip, and then washed twice with serum-free medium and further incubated in DMEM medium with $1 \%$ serum. Images of the wounded monolayer of 
HUVECs were taken at 12 and $24 \mathrm{~h}$ after treatment with complex 6 by using an Olympus microscope system.

\section{Conclusions}

Generally, luminescent probes are classified into three types: "always-on", "turn-on" or "turn-off", based on their luminescence behavior upon interaction with analytes. ${ }^{56,57}$ Always-on (permanent) or turn-on luminescent probes are preferred because of their lower target-to-background ratio, while "turn-off" probes may suffer from luminescence quenching by energy transfer mechanisms due to interactions with biological interferents. ${ }^{56,58}$ In this work, we designed and synthesized a WKYMVmconjugated iridium(III) complex (6) as a permanent FPR2 imaging probe. This probe showed a long luminescence lifetime of $4.62 \mu \mathrm{s}$ and good photostability. In luminescence imaging experiments, the probe "lighted up" FPR2-expressing HUVEC cells in a dose- and time-dependent manner. WRW4 agonist competition and siRNA knockdown experiments provided further evidence that the probe selectively targeted FPR2 in HUVEC cells. Importantly, the probe was relatively nontoxic at the concentrations required for cell imaging. FPR2 silencing decreased the migration capacity of HUVEC cells in the scratch assay, verifying the role of the FPR2 in epithelial cells. Significantly, our probe decreased the migration of HUVEC cells both in the absence and presence of the FPR2 agonist LXA4, revealing its FPR2 inhibitory role in living HUVEC cells. These results show that the peptideconjugated probe not only effectively recognizes FPRs, but also regulates FPR2-mediated functions in living cells. To the best of our knowledge, this is the first long-lived probe reported for FPR2 cellular imaging, and we anticipate that it could serve as a good starting point for the development of other kinds of luminescent FPR2 probes or possibly new drugs for the treatment of inflammatory diseases.

\section{Conflicts of interest}

There are no conflicts to declare.

\section{Acknowledgements}

This work is supported by Hong Kong Baptist University (FRG2/ 16-17/007 and FRG2/17-18/003), the Health and Medical Research Fund (HMRF/14150561), the Research Grants Council (HKBU/12301115), the National Natural Science Foundation of China (21575121, 21775131, and 21628502), the Hong Kong Baptist University Century Club Sponsorship Scheme 2018, the Interdisciplinary Research Matching Scheme (RC-IRMS/16-17/ 03), Interdisciplinary Research Clusters Matching Scheme (RC-IRCs/17-18/03), Innovation and Technology Fund (ITS/260/ 16FX), Matching Proof of Concept Fund (MPCF-001-2017/18), Collaborative Research Fund (C5026-16G), SKLEBA and HKBU Strategic Development Fund (SKLP_1718_P04), the Science and Technology Development Fund, Macao SAR (077/2016/A2), and the University of Macau (MYRG2016-00151-ICMS-QRCM and MYRG2018-00187-ICMS).

\section{Notes and references}

1 Y. Le, P. M. Murphy and J. M. Wang, Trends Immunol., 2002, 23, 541-548.

2 D. Y. Richard, F. Boulay, J. M. Wang, C. Dahlgren, C. Gerard, M. Parmentier, C. N. Serhan and P. M. Murphy, Pharmacol. Rev., 2009, 61, 119-161.

3 N. Prevete, F. Liotti, G. Marone, R. M. Melillo and A. de Paulis, Pharmacol. Res., 2015, 102, 184-191.

4 R. Koczulla, G. Von Degenfeld, C. Kupatt, F. Krötz, S. Zahler, T. Gloe, K. Issbrücker, P. Unterberger, M. Zaiou and C. Lebherz, J. Clin. Invest., 2003, 111, 1665.

5 G. Shao, M. W. Julian, S. Bao, M. K. McCullers, J.-P. Lai, D. L. Knoell and E. D. Crouser, Am. J. Respir. Cell Mol. Biol., 2011, 44, 264-269.

6 G. Leoni, A. Alam, P.-A. Neumann, J. D. Lambeth, G. Cheng, J. McCoy, R. S. Hilgarth, K. Kundu, N. Murthy and D. Kusters, J. Clin. Invest., 2012, 123, 443-454.

7 Y. Li and D. Ye, J. Mol. Med., 2013, 91, 781-789.

8 H. R. Herschman, Science, 2003, 302, 605-608.

9 T. F. Massoud and S. S. Gambhir, Genes Dev., 2003, 17, 545580.

10 J. C. Reubi and H. R. Maecke, J. Nucl. Med., 2008, 49, 17351738.

11 T. Uhlig, T. Kyprianou, F. G. Martinelli, C. A. Oppici, D. Heiligers, D. Hills, X. R. Calvo and P. Verhaert, EuPa Open Proteomics, 2014, 4, 58-69.

12 G. J. Stasiuk, H. Smith, M. Wylezinska-Arridge, J. L. Tremoleda, W. Trigg, S. K. Luthra, V. M. Iveson, F. N. Gavins and N. J. Long, Chem. Commun., 2013, 49, 564-566.

13 G. J. Stasiuk, P. M. Holloway, C. Rivas, W. Trigg, S. K. Luthra, V. Morisson Iveson, F. N. E. Gavins and N. J. Long, Dalton Trans., 2015, 44, 4986-4993.

14 X. Yang, M. D. Chordia, X. Du, J. L. Graves, Y. Zhang, Y. S. Park, Y. Guo, D. Pan and Q. Cui, J. Orthop. Res., 2016, 34, 1529-1538.

15 J. Li, Y. Zhang, M. D. Chordia, H. Wu, L. Shao and D. Pan, Bioorg. Med. Chem. Lett., 2016, 26, 1052-1055.

16 K. A. Stephenson, S. R. Banerjee, T. Besanger, O. O. Sogbein, M. K. Levadala, N. McFarlane, J. A. Lemon, D. R. Boreham, K. P. Maresca, J. D. Brennan, J. W. Babich, J. Zubieta and J. F. Valliant, J. Am. Chem. Soc., 2004, 126, 8598-8599.

17 V. Ntziachristos, Annu. Rev. Biomed. Eng., 2006, 8, 1-33.

18 J. Deguchi, M. Aikawa, C. H. Tung, E. Aikawa, D. E. Kim, V. Ntziachristos, R. Weissleder and P. Libby, Circulation, 2006, 114, 55-62.

19 J. Chen, C.-H. Tung, J. R. Allport, S. Chen, R. Weissleder and P. L. Huang, Circulation, 2005, 111, 1800-1805.

20 D. Maxwell, Q. Chang, X. Zhang, E. M. Barnett and D. Piwnica-Worms, Bioconjugate Chem., 2009, 20, 702-709.

21 E. M. Barnett, X. Zhang, D. Maxwell, Q. Chang and D. Piwnica-Worms, Proc. Natl. Acad. Sci. U. S. A., 2009, 106, 9391-9396.

22 G. Blum, G. Von Degenfeld, M. J. Merchant, H. M. Blau and M. Bogyo, Nat. Chem. Biol., 2007, 3, 668-677. 
23 L. Xiao, Y. Zhang, S. S. Berr, M. D. Chordia, P. Pramoonjago, L. Pu and D. Pan, Mol. Imaging, 2012, 11, 372-382.

24 H. Forsman, J. Bylund, T. I. Oprea, A. Karlsson, F. Boulay, M.-J. Rabiet and C. Dahlgren, BBA, Biochim. Biophys. Acta, Mol. Cell Res., 2013, 1833, 1914-1923.

25 T. U. Connell and P. S. Donnelly, Coord. Chem. Rev., 2017, 375, 267-284.

26 A. M.-H. Yip and K. K.-W. Lo, Coord. Chem. Rev., 2018, 361, 138-163.

27 V. Fernandez-Moreira, F. L. Thorp-Greenwood and M. P. Coogan, Chem. Commun., 2010, 46, 186-202.

28 E. Baggaley, J. A. Weinstein and J. A. G. Williams, Coord. Chem. Rev., 2012, 256, 1762-1785.

29 M. Soler, L. Feliu, M. Planas, X. Ribas and M. Costas, Dalton Trans., 2016, 45, 12970-12982.

30 E. Koren and V. P. Torchilin, Trends Mol. Med., 2012, 18, 385393.

31 N. Metzler-Nolte, in Medicinal Organometallic Chemistry, Springer, 2010, pp. 195-217.

32 F. Noor, A. Wüstholz, R. Kinscherf and N. Metzler-Nolte, Angew. Chem., Int. Ed., 2005, 44, 2429-2432.

33 C. A. Puckett and J. K. Barton, Bioorg. Med. Chem., 2010, 18, 3564-3569.

34 E. M. Hahn, N. Estrada-Ortiz, J. Han, V. F. Ferreira, T. G. Kapp, J. D. Correia, A. Casini and F. E. Kühn, Eur. J. Inorg. Chem., 2017, 2017, 1667-1672.

35 Y. You, Curr. Opin. Chem. Biol., 2013, 17, 699-707.

36 Y. You and W. Nam, Chem. Soc. Rev., 2012, 41, 7061-7084.

37 J. Kuil, P. Steunenberg, P. T. Chin, J. Oldenburg, K. Jalink, A. H. Velders and F. W. van Leeuwen, ChemBioChem, 2011, 12, 1897-1903.

38 X. Wang, J. Jia, Z. Huang, M. Zhou and H. Fei, Chem.-Eur. J., 2011, 17, 8028-8032.

39 K. Koren, R. I. Dmitriev, S. M. Borisov, D. B. Papkovsky and I. Klimant, ChemBioChem, 2012, 13, 1184-1190.

40 Y. Hisamatsu, A. Shibuya, N. Suzuki, T. Suzuki, R. Abe and S. Aoki, Bioconjugate Chem., 2015, 26, 857-879.

41 C. Dolan, R. D. Moriarty, E. Lestini, M. Devocelle, R. J. Forster and T. E. Keyes, J. Inorg. Biochem., 2013, 119, 65-74.
42 X. Ma, J. Jia, R. Cao, X. Wang and H. Fei, J. Am. Chem. Soc., 2014, 136, 17734-17737.

43 S. D. Kim, S. Kwon, S. K. Lee, M. Kook, H. Y. Lee, K.-D. Song, H.-K. Lee, S.-H. Baek, C. B. Park and Y.-S. Bae, Exp. Mol. Med., 2013, 45, e40.

44 Y. H. Choi, I. H. Jang, S. C. Heo, J. H. Kim and N. S. Hwang, Organogenesis, 2016, 12, 53-60.

45 S. C. Heo, Y. W. Kwon, I. H. Jang, G. O. Jeong, J. W. Yoon, C. D. Kim, S. M. Kwon, Y. S. Bae and J. H. Kim, Stem Cells, 2014, 32, 779-790.

46 Y. W. Kwon, S. C. Heo, I. H. Jang, G. O. Jeong, J. W. Yoon, J. H. Mun and J. H. Kim, Wound Repair Regen., 2015, 23, 575-582.

47 F. Cattaneo, M. Parisi and R. Ammendola, Int. J. Mol. Sci., 2013, 14, 7193-7230.

48 H. Y. Lee, H. Kim, S. Y. Lee, Y. S. Jung, S. D. Kim and Y.-S. Bae, Pharmazie, 2014, 69, 293-296.

49 R. Cole, Cell Adhes. Migr., 2014, 8, 452-459.

50 A. Ettinger and T. Wittmann, in Methods Cell Biol., Elsevier, 2014, vol. 123, pp. 77-94.

51 Z. Liu, L. D. Lavis and E. Betzig, Mol. Cell, 2015, 58, 644-659. 52 S. Zheng, V. K. Souza, D. Bartis, R. C. A. Dancer, D. Parekh, B. Naidu, F. Gao-Smith, Q. Wang, S. Jin, Q. Lian and D. R. Thickett, ERJ Open Res., 2016, 2, 00079-2015.

53 C.-C. Liang, A. Y. Park and J.-L. Guan, Nat. Protoc., 2007, 2, 329-333.

54 A. S. Gilder, L. Wang, L. Natali, N. Karimi-Mostowfi, C. Brifault and S. L. Gonias, PLoS One, 2016, 11, e0168418.

55 P. J. Buchanan, P. McNally, B. J. Harvey and V. Urbach, Am. J. Physiol., 2013, 305, L193-L201.

56 H. Kobayashi and P. L. Choyke, Acc. Chem. Res., 2010, 44, 8390.

57 A. P. De Silva, H. N. Gunaratne, T. Gunnlaugsson, A. J. Huxley, C. P. McCoy, J. T. Rademacher and T. E. Rice, Chem. Rev., 1997, 97, 1515-1566.

58 P. L. Choyke and H. Kobayashi, IEEE J. Sel. Top. Quantum Electron., 2012, 18, 1140-1146. 